\title{
ELECTING A MEGA-MAYOR
}

\section{Toronto 2014}

Electing a Mega-Mayor represents the first-ever comprehensive, surveybased examination of a Canadian mayoral race and provides a unique, detailed account of the 2014 mayoral election in Toronto. After making the case that local elections deserve more attention from scholars of political behaviour, this book offers readers an understanding of Toronto politics at the time of the 2014 election and presents relevant background on the major candidates. It considers the importance that Torontonians attached to policy concerns and identifies the bases of support for the outgoing, scandal-ridden mayor, Rob Ford, and his brother Doug.

In the penultimate chapter, the authors examine how Torontonians viewed their elected officials, and the city's performance, two years after the election. McGregor, Moore, and Stephenson conclude with a reflection on what the analysis of the Toronto 2014 election says about voters in large cities in general and provide a short epilogue addressing the 2018 election results. Written in an accessible style, this is the first book on the politics of Toronto during the Ford era that focuses on the perspective of the voter.

R. MICHAEL MCGREGOR is an assistant professor in the Department of Politics and Public Administration at Ryerson University.

AARon A. MOORE is an associate professor in the Department of Political Science at the University of Winnipeg.

Laura B. Stephenson is a professor in the Department of Political Science at the University of Western Ontario. 
This page intentionally left blank 


\section{Electing a Mega-Mayor}

Toronto 2014

R. MICHAEL McGREGOR, AARON A. MOORE, AND LAURA B. STEPHENSON

UNIVERSITY OF TORONTO PRESS

Toronto Buffalo London 
(C) University of Toronto Press 2021

Toronto Buffalo London

utorontopress.com

Printed in the U.S.A.

ISBN 978-1-4875-0963-7 (cloth)ＩSBN 978-1-4875-0966-8 (EPUB)

ISBN 978-1-4875-0964-4 (paper) ISBN 978-1-4875-0965-1 (PDF)

\section{Library and Archives Canada Cataloguing in Publication}

Title: Electing a mega-mayor : Toronto 2014 / R. Michael McGregor,

Aaron A. Moore, and Laura B. Stephenson.

Other titles: Toronto 2014

Names: McGregor, R. Michael, author. | Moore, Aaron A., 1979-, author. |

Stephenson, Laura Beth, 1976-, author.

Description: Includes bibliographical references and index.

Identifiers: Canadiana (print) 2021015621X | Canadiana (ebook)

2021015649X | ISBN 9781487509644 (paper) | ISBN 9781487509637

(cloth) | ISBN 9781487509668 (EPUB) | ISBN 9781487509651 (PDF)

Subjects: LCSH: Mayors - Ontario - Toronto - Election. | LCSH: Local

elections - Ontario - Toronto. | LCSH: Political candidates - Ontario -

Toronto. | LCSH: Political campaigns - Ontario - Toronto. | LCSH: Voting -

Ontario - Toronto. | LCSH: Toronto (Ont.) - Politics and government -

21st century.

Classification: LCC JS1789.73 .M34 2021 | DDC 324.9713/541 - dc23

University of Toronto Press acknowledges the financial assistance to its publishing program of the Canada Council for the Arts and the Ontario Arts Council, an agency of the Government of Ontario.

Canada Council for the Arts
Conseil des Arts du Canada
ONTARIO ARTS COUNCIL CONSEIL DES ARTS DE L'ONTARIO

an Ontario government agency un organisme du gouvernement de l'Ontario
un 